\title{
A Simple System for Two-Point Parallel Initiation of Explosive
}

\author{
Uroš Anđelić ${ }^{1)}$ \\ Danica Simic ${ }^{1)}$
}

\begin{abstract}
A simultaneous initiation of an explosive charge from two or more points can generate a localized increase in pressure, and other detonation parameters, in relation to the stable detonation of the used explosive. To achieve this increase in parameters, more or less complex initiation system has to be utilized. This paper presents a simple and inexpensive system for a simultaneous and parallel two-point initiation of an explosive charge. This system consists of a primary explosive - initiator and an attenuator made of polyetilene with two cylindrical channels - initiation points, filled with plastic explosive. The channels were placed at $24 \mathrm{~mm}$ distance from each other, but any distance can be used. The experiments confirmed that a simultaneous initiation was achieved.
\end{abstract}

Key words: explosives, explosive charge, explosive initiation, detonation, detonation parameters, experimental results.

\section{Introduction}

$\mathrm{W}$ HEN two shock waves (SW) or detonation waves (DW) collide, a regular or irregular interaction occurs, depending on their intensity, and the angle between them. In case of two plane waves that angle is constant, and with two divergent waves, the angle increases over time. Regular interaction occurs directly after a collision of two divergent waves because the angle of collision is large. When that angle becomes sufficiently small, a Mach detonation wave (Mach wave) can be formed, if the DW intensity is sufficiently large. A Mach wave is a bridge that arises and grows between two DW. Its hydrodynamic properties are different from initial DW properties, i.e. 2 - 3 times greater detonation velocity and pressure. Therefore, two- or more point initiation with an adequate arrangement can give a localized increase in brisance of the used explosive charge.

Interaction of two DW may result in three characteristic forms, depending on their intensity and on the angle of their interaction (Fig.1) [1].

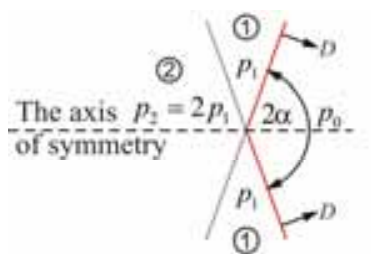

a)

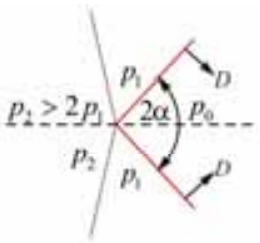

b)

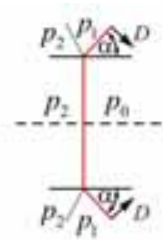

c)
Figure 1. Interaction of two DW with different intensities: a) low, b) medium, c) high

Compared to the low intensity DW interactions (Fig.1a), during medium intensity DW interactions (Fig.1b), the pressure $p_{2}$ in the zone 2 grows over the $2 p_{1}$ value, and the angle between the DW and the axis of symmetry, $\alpha$, becomes smaller. In case of high intensity DW interactions (Fig.1c) a Mach wave is formed.

Over the years, different ways of initiation were used to achieve and study DW interactions and the formation of a Mach wave. Theoretical and experimental research on this matter was done extensively, because of a high demand of multi-initiating systems for military and civil purposes.

In the explosive in shaped charge warheads, which is axially symmetrical, the DW is often reshaped by inserting an inert cylindrical or active hemispherical wave shaper between the detonator and the cone shaped end of the explosive charge [1 - 3]. The diameter of the wave shaper is smaller than the diameter of the explosive charge, so that the DW can go around it (Fig.2a). After it passes the wave shaper, the ring-shaped DW converges and interacts with itself, and potentially forms a Mach wave. In ref. [1], the numerical simulations by the finite element method were used to observe the propagation of the DW through and around the wave shaper, and through the explosive charge, and the mechanism of attenuation of the shock wave intensity and velocity. In ref. [2, 3], the shape of the DW was experimentally determined using a streak recording camera. Active and passive hemispherical wave shaper was used to change the shape and the velocity of the DW. It was found that, when using the active wave shaper, a DW with a higher intensity of the detonation parameters is produced, which has a Mach wave as a result.
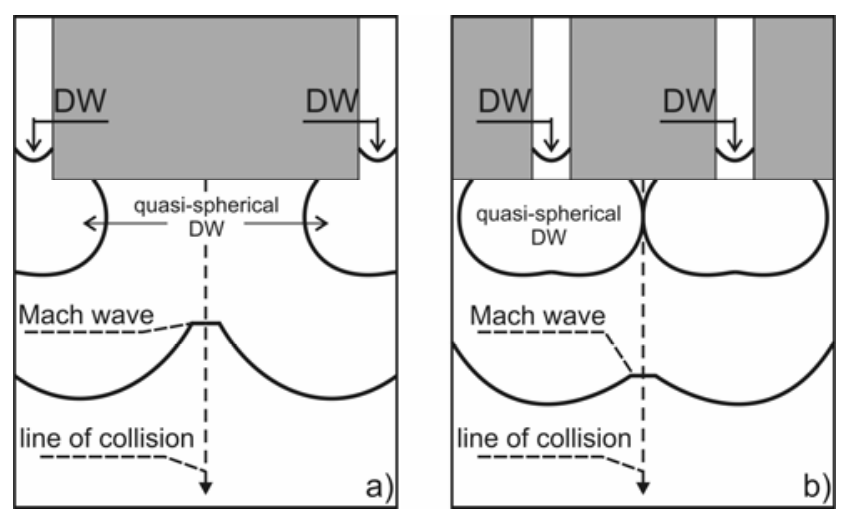

Figure 2. Mach wave formation scheme: a) ring-shaped DW convergence, b) two-point initiation by explosive slabs

\footnotetext{
1) Military Technical Institute (VTI), Ratka Resanovića 1, 11132 Belgrade, SERBIA

Correspondence to: Uroš Anđelić, email: uroshcs@gmail.com
} 
Another way to form a Mach wave is to initiate an explosive charge in two parallel points simultaneously. The timing and the geometry of the two initiators has to be very precise in order to form a Mach wave at a specific point in the explosive. Double initiation can be done with two parallel channels made of two explosive slabs [4]. The slabs act as two point initiators, and each forms a quasi-spherical DW [5]. The interaction of these two DW allows the formation of a Mach wave (Fig.2b). Mach wave can also be formed between two plane waves that collide at a certain angle [6]. Plane waves can be obtained either by two explosive plane wave generators, or by two gas guns. There are several other, specific ways to achieve double initiation, like using two parallel line wave generators [7].

This work presents a simple way to obtain simultaneous, parallel initiation of an explosive charge in two points.

\section{Experimental model}

The two-point initiation model consists of an initiator and an attenuator, as presented in Fig.3. For the single point initiation of the primary explosive - initiator, a detonating cap DK-8 was used. Two different primary explosives were tested, a regular booster, and a plane wave generator. The whole model is cylinder-shaped.

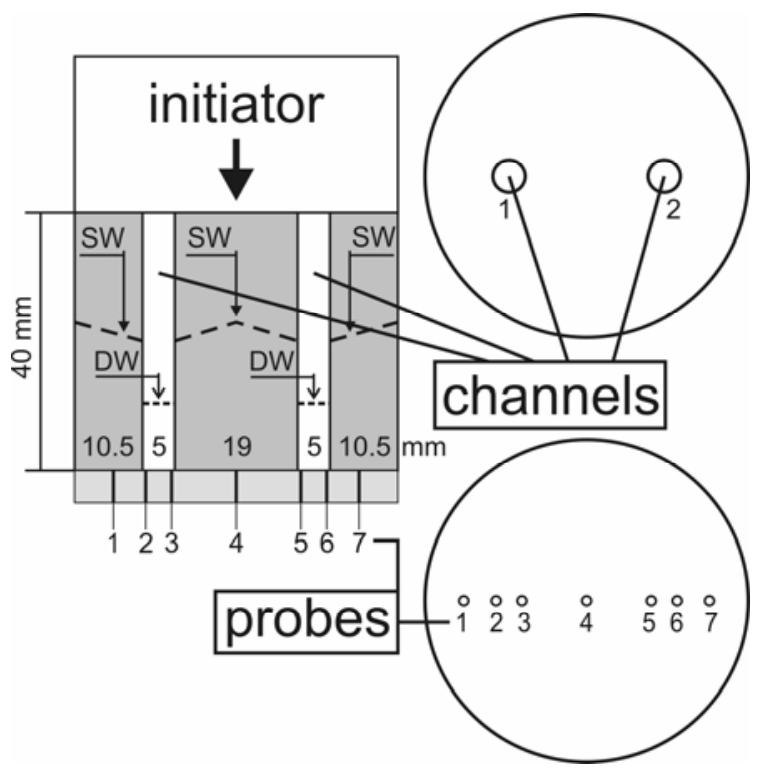

Figure 3. Experimental model principle

Quasi-spherical or plane DW from the primary explosive is split into two channels by the attenuator. The attenuator is a $50 \mathrm{~mm}$ diameter cylinder, $40 \mathrm{~mm}$ high, with two cylindrical, 5 $\mathrm{mm}$ diameter channels, $24 \mathrm{~mm}$ apart from each other, and it is made of polyetilene. These channels make the model plane symmetric. The channels are filled with plastic explosive PEP-500, as presented in Fig.4.

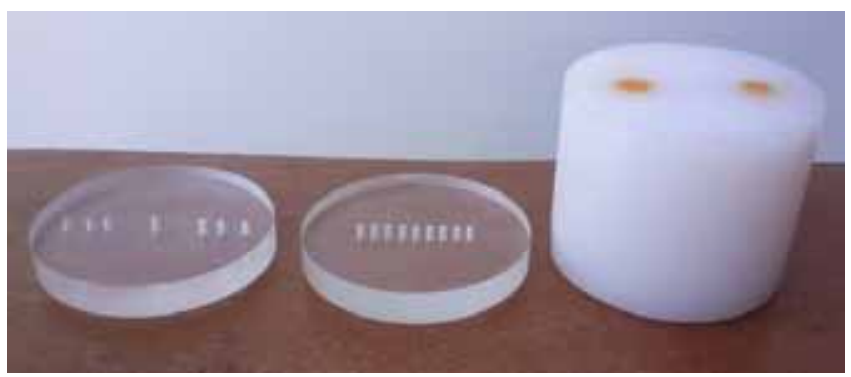

Figure 4. Seven-probes platform (left), nine-probes platform (middle) and the plastic attenuator with two PEP-500 channels (right)
After the DW exits the primary explosive it continues as a SW through the attenuator, and as a DW through the explosive filled channels. Since the DW velocity is greater than the SW velocity, the two channels should simultaneously initiate the acceptor explosive, while the rest of the attenuator's surface, which is in contact with the acceptor explosive, is still undisturbed. In order to test this mechanism, the detonation and shock wave arrival time were measured by seven ionization probes [8]. Two probes were placed at each of the channels to time the DW, and three remaining probes were placed accordingly to time the arrival of the SW.

As previously mentioned, two different initiators were used. The booster explosive used is FH-5 (hexogen/viton $95 / 5$ ), pressed to $40 \mathrm{~mm}$ diameter. This diameter is enough to comprise and initiate both plastic explosive channels on the attenuator (Fig.5).

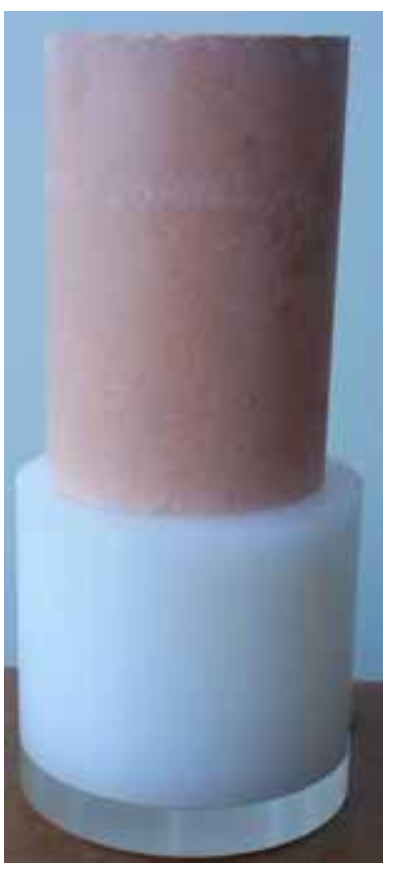

Figure 5. Booster-attenuator two-point initiation system

\section{Results and discussion}

The results are presented in Table 1 and Fig.6. The first probe that recorded a signal was used as a reference probe $(t=0)$ in each experiment.

The achieved delay of the SW is between $1.77 \mu$ s and 6.25 $\mu$ s wich is quite satisfactory, considering the dimensions of the channels and their distance. Since both the booster and the plane wave generator give good results, the booster was chosen as the initiator because it is much more simple and economic choice.

Table 1. DW/SW arrival time for 7 probes

\begin{tabular}{|c|c|c|c||}
\hline \multirow{2}{*}{ Probe number } & \multirow{2}{*}{$\begin{array}{c}\text { Probe position, } \\
X(\mathrm{~mm})\end{array}$} & \multicolumn{2}{|c|}{ DW/SW arrival time, $t(\mu \mathrm{s})$} \\
\cline { 3 - 4 } & 6 & 3,57 & 1,83 \\
\hline \hline 1-SW* $^{*}$ & 6 & 0,01 & 0 \\
\hline 2 & 11 & 0 & 0,07 \\
\hline 3 & 15 & 1,77 & 6,25 \\
\hline $4-\mathrm{SW}$ & 25 & 0,02 & 0,14 \\
\hline 5 & 35 & 0,02 & 0,15 \\
\hline 6 & 39 & 3,78 & 3,93 \\
\hline $7-S W$ & 44 & Plane & initiation \\
\hline
\end{tabular}

* probes that measured SW arrival time on the attenuator 

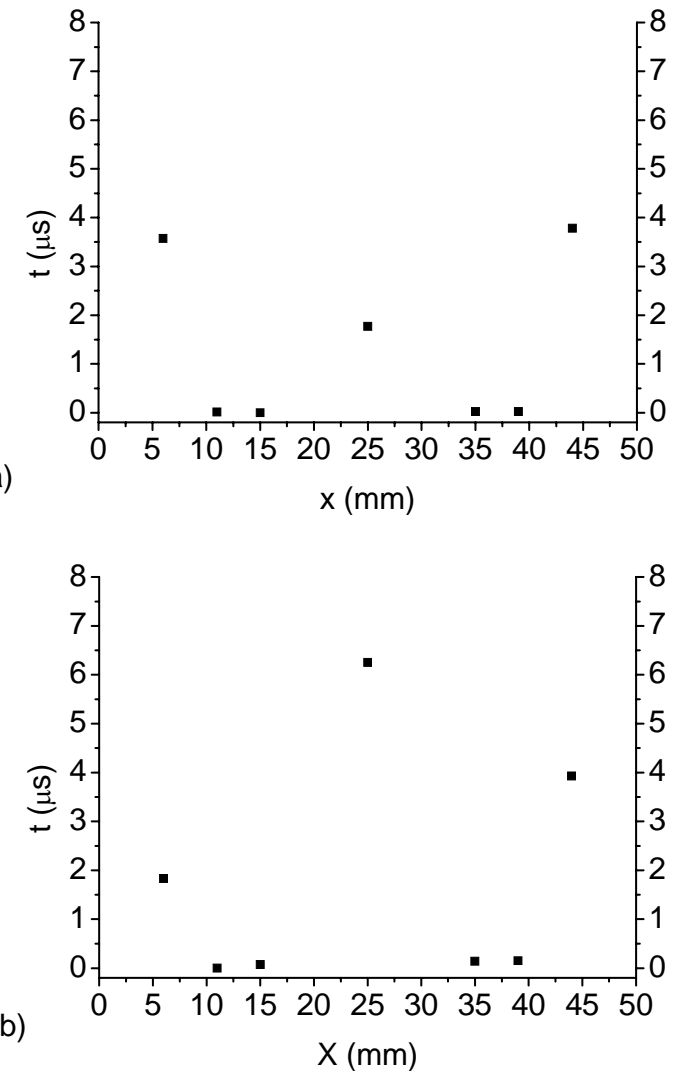

Figure 6. DW/SW arrival time for 7 probes with booster (a) and with plane wave generator (b) initiation

Further testing was done by adding an acceptor explosive at the end of the attenuator, as presented in Fig.7, and measuring the shape of the DW, obtained from the two-point initiation. The explosive used was a $50 \mathrm{~mm}$ diameter cast PBX of the HMX/HTPB 80/20 chosen composition. In order to measure the shape of the DW at different distances from the initiation line, the cylindrical explosive was cut to different heights: $12 \mathrm{~mm}, 24 \mathrm{~mm}, 36 \mathrm{~mm}, 48 \mathrm{~mm}$, and 60 $\mathrm{mm}$. The smallest height of $12 \mathrm{~mm}$ was chosen as a half of the distance between the two plastic explosive initiator channels. The shape of the DW was recorded by nine ionization probes placed in a line with a step of $3 \mathrm{~mm}$. The fifth probe was placed at the center having four probes on each side. This way, all $24 \mathrm{~mm}$ between the initiating channels were covered. Two experiments were done for each height of the acceptor explosive, and the results are presented in Table 2.

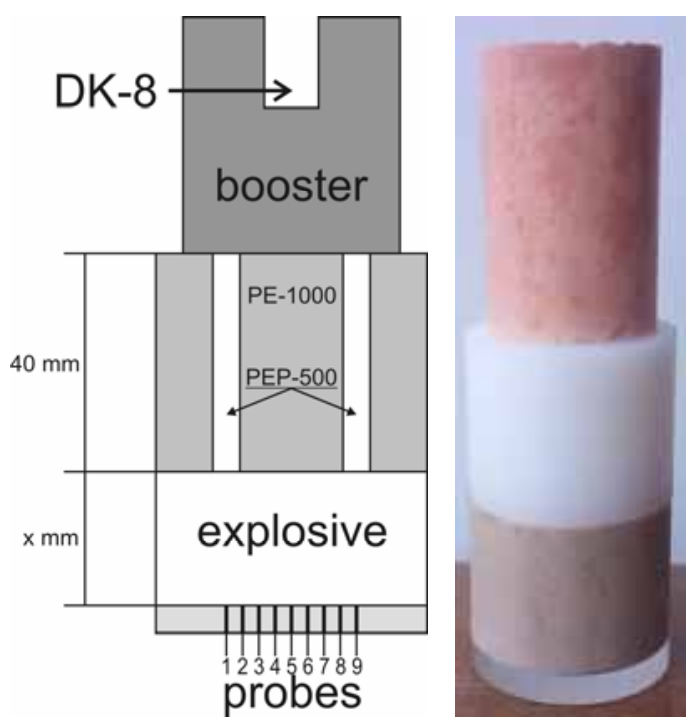

Figure 7. Experimental setup for measuring the shape of the DW
Table 2. DW arrival time for 9 probes

\begin{tabular}{|c|c|c|c|c|c|c|c|c|c|c|c|}
\hline \multirow{3}{*}{$\begin{array}{c}\text { Probe } \\
\text { number }\end{array}$} & \multirow{3}{*}{$\begin{array}{c}\begin{array}{c}X \\
(\mathrm{~mm})\end{array} \\
13 \\
\end{array}$} & \multicolumn{10}{|c|}{ DW arrival time, $t$ (ns) } \\
\hline & & \multicolumn{2}{|c|}{$12 \mathrm{~mm}$} & \multicolumn{2}{|c|}{$24 \mathrm{~mm}$} & \multicolumn{2}{|c|}{$36 \mathrm{~mm}$} & \multicolumn{2}{|c|}{$48 \mathrm{~mm}$} & \multicolumn{2}{|c|}{$60 \mathrm{~mm}$} \\
\hline & & $-*$ & - & 0 & 0 & 0 & 0 & - & - & - & 0 \\
\hline 2 & 16 & 70 & - & 19 & 30 & 120 & 20 & 0 & - & - & 20 \\
\hline 3 & 19 & 110 & - & 79 & 270 & 181 & 70 & 19 & 100 & - & 80 \\
\hline 4 & 22 & 200 & - & 250 & 200 & 210 & 180 & 100 & 140 & - & 120 \\
\hline 5 & 25 & 410 & - & 340 & 330 & 290 & 270 & 150 & 210 & - & 150 \\
\hline 6 & 28 & 180 & - & 240 & 290 & 200 & - & - & 150 & - & 120 \\
\hline 7 & 31 & 30 & - & - & 190 & 110 & 110 & - & 80 & - & 100 \\
\hline 8 & 34 & 0 & - & 60 & - & - & 130 & 90 & 10 & - & 80 \\
\hline 9 & 37 & - & - & 60 & 90 & 10 & - & 80 & 0 & - & - \\
\hline
\end{tabular}

* failed probe measurements

Table 3. Averaged DW arrival time, and length latency for 9 probes

\begin{tabular}{|c|c|c|c|c|c|c|c|c|c|c|c|}
\hline \multirow{3}{*}{$\begin{array}{l}\text { Probe } \\
\text { number }\end{array}$} & \multirow{3}{*}{$\begin{array}{c}X \\
(\mathrm{~mm})\end{array}$} & \multicolumn{10}{|c|}{$\begin{array}{c}\text { Averaged DW arrival time, } t_{s}(\mathrm{~ns}) \text {, and length latency, } Y \\
(\mathrm{~mm})\end{array}$} \\
\hline & & \multicolumn{2}{|c|}{$12 \mathrm{~mm}$} & \multicolumn{2}{|c|}{$24 \mathrm{~mm}$} & \multicolumn{2}{|c|}{$36 \mathrm{~mm}$} & \multicolumn{2}{|c|}{$48 \mathrm{~mm}$} & \multicolumn{2}{|c|}{$60 \mathrm{~mm}$} \\
\hline & & $t_{s}$ & $Y$ & $t_{s}$ & $Y$ & $t_{s}$ & $Y$ & $t_{s}$ & $Y$ & $t_{s}$ & $Y$ \\
\hline 1 & 13 & - & - & 38 & 0,33 & 3 & 0,03 & 40 & 0,35 & 0 & 0 \\
\hline 2 & 16 & 35 & 0,30 & 36 & 0,31 & 70 & 0,61 & 33 & 0,29 & 50 & 0,43 \\
\hline 3 & 19 & 70 & 0,61 & 126 & 1,09 & 118 & 1,02 & 67 & 0,58 & 90 & 0,78 \\
\hline 4 & 22 & 190 & 1,65 & 245 & 2,13 & 195 & 1,69 & 130 & 1,13 & 120 & 1,04 \\
\hline 5 & 25 & 410 & 3,56 & 335 & 2,91 & 280 & 2,43 & 180 & 1,56 & 150 & 1,30 \\
\hline 6 & 28 & 190 & 1,65 & 245 & 2,13 & 195 & 1,69 & 130 & 1,13 & 120 & 1,04 \\
\hline 7 & 31 & 70 & 0,61 & 126 & 1,09 & 118 & 1,02 & 67 & 0,58 & 90 & 0,78 \\
\hline 8 & 34 & 35 & 0,30 & 36 & 0,31 & 70 & 0,61 & 33 & 0,29 & 50 & 0,43 \\
\hline 9 & 37 & - & - & 38 & 0,33 & 3 & 0,03 & 40 & 0,35 & 0 & 0 \\
\hline
\end{tabular}

The results were averaged for each height of the acceptor explosive, and also for the equivalent probes (1 and 9, 2 and 8,3 and 7 , and 4 and 6). DW arrival time was transformed to length latency, $\mathrm{Y}$, by using the detonation velocity of the acceptor explosive in order to obtain the shape of the DW, presented in Fig. 8. Since the analyzed DW was in an unstable state, this is just an approximation of the real value of $Y$, i.e. the shape of the DW.

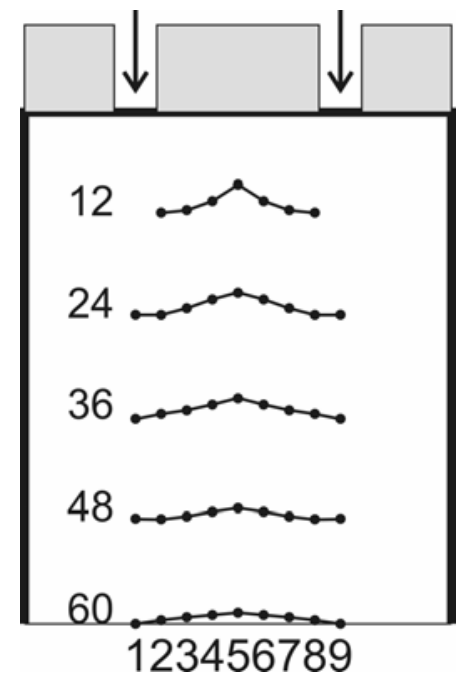

Figure 8. The shape of the DW measured by probes placed at different distances $(12,24,36,48$ and $60 \mathrm{~mm})$ from the two-point initiation line

\section{Conclusions}

Results from the testing of the model show that the difference in the time of arrival between the SW, which propagates through the attenuator, and the DW, which propagates through the plastic explosive channels, is more than enough to conclude that the acceptor explosive is indeed 
initiated only from the two channels.

The obtained shape of the DW in the acceptor explosive confirms that the parallel two-point initiation was achieved with this experimental setup. The results for different distances $(12 \mathrm{~mm}-60 \mathrm{~mm})$ from the double initiation show the evolution of the detonation wave through the explosive charge. With more distance, the DW continues to stabilize and eventually achieves constant shape and velocity, characteristic to the shape and composition of the explosive used.

The two-point initiation system, shown in this work, presents a good base for further studies of simultaneous initiation. However, it is impossible to see whether or not the Mach wave was formed, because the resolution, used for measuring the shape of the DW, was too small - only 9 points of measurement with the $3 \mathrm{~mm}$ step. Future research will include experiments with optic probes instead of ionization probes, which allow smaller steps - more measuring points in order to observe and study the Mach wave formed with this particular setup.

\section{References}

[1] UGRČIĆ,M., BLAGOJEVIĆ,M., BAJIĆ,Z.: Teorijski aspekti $i$ numerička simulacija kumulativnog efekta, KumNTI 3/2012, ISSN 1820-3418, ISBN 978-86-81123-53-9, Vojnotehnički institut, Beograd, Serbia, 2012, Vol.XLVIII, No.3.
[2] UGRČIĆ,M.: Ispitivanje transformacije oblika i brzine detonacionog talasa u kumulativnom punjenju sa hemisferičnim devijatorom, Naučnotehnički pregled, ISSN 0350-0667, 1990, Vol.XL, No.8-9, pp.49-57.

[3] UGRČIĆ,M., BLAGOJEVIĆ,M.: Theoretical and experimental method for determination of detonation wave parameters in the charge with hemispherical wave shaper, Scientific Technical Review, ISSN 1820-0206, 2002, Vol.LII, No.3, pp.23-28.

[4] MENDES,R., PLAKSIN,I., CAMPOS,J.: Double initiation and Mach formation in $P B X$, Eleventh International Detonation Symposium, 1998, pp.399- 406 .

[5] HULL,L.M.: Mach reflection of spherical detonation waves, 10th International Detonation Symposium, Boston, Massachusetts, July 1216, 1993.

[6] ARGOUS,J.P., PEYRE,C., THOUVENIN,J.: Observation et étude des conditions de formation d'une onde de détonation de Mach, Journal de Physique, 1966, 27 (3-4), pp.190-195.

[7] MADER,C.L.: Detonation wave interactions, Los Alamos National Laboratory, New Mexico, 01/1981.

[8] DŽINGALAŠEVIĆ,V., JELAČA,Z., UGRČIĆ,M.: Application of the method for time intervals multichannel measuring using electrical gauges for detonation testing, Naučnotehnički pregled, ISSN 03500667, 2001, Vol.LI, No.6, pp.112-118.

\title{
Jednostavan sistem za paralelno iniciranje eksploziva u dve tačke
}

\begin{abstract}
Istovremeno iniciranje eksplozivnog punjenja iz dve ili više tačaka može da izazove lokalizovani porast pritiska i drugih detonacionih parametara u odnosu na stabilnu detonaciju korišćenog eksploziva. Da bi se postigao ovaj porast parametara, mora da se upotrebi više ili manje kompleksan sistem za inicijaciju. Ovaj rad predstavlja jednostavan i jeftin sistem za istovremenu i paralelnu inicijaciju eksplozivnog punjenja u dve tačke. Ovaj sistem se sastoji od primarnog eksploziva inicijatora i od atenuatora, napravljenog od polietilena, sa dva cilindrična kanala - tačkama inicijacije, koji su napunjeni plastičnim eksplozivom. Kanali su napravljeni na rastojanju od $24 \mathrm{~mm}$ jedan od drugog, ali može da se koristi bilo koje rastojanje. Eksperimenti su potvrdili da je postignuta istovremena inicijacija.
\end{abstract}

Ključne reči: eksplozivi, eksplozivno punjenje, inicijacija eksploziva, detonacija, parametri detonacije, eksperimentalni rezultati.

\section{Простая система для параллельного возбуждения взрывчатых веществ в двух точках}

\begin{abstract}
Одновременное инициирование заряда взрывчатого вещества в двух или в нескольких точках может вызвать локализованное увеличение давления и других параметров детонации по отношению к стабильной детонации использованных взрывчатых веществ. Для достижения этого увеличения параметров, нужно использовать более или менее сложную систему инициации. Эта статья представляет собой простую и недорогую систему для одновременного и параллельного начала инициации зарядов взрывчатых веществ в двух точках.Эта система состоит из первичного взрывчатого вещества - инициатора и аттенюатора из полиэтилена, с двумя цилиндрическими каналами - точками инициации, которые заполнены пластическим взрывчатым веществом. Каналы выполнены на расстоянии 24 мм друг от друга, но могут быть использованы для любого расстояния. Эксперименты подтвердили, что получена совместная одновременная инициация.
\end{abstract}

Ключевые слова: взрывчатые вещества, заряд взрывчатого вещества, инициирование взрывчатых веществ, детонация, параметры детонации, результаты экспериментов. 


\section{Un système simple pour l'initiation parallèle de l'explosif à deux points}

L'initiation simultanée de la charge explosive à partir de deux ou plusieurs points peut provoquer une croissance locale de pression ainsi que d'autres paramètres par rapport à la détonation stable de l'explosif utilisé. Pour produire cette croissance des paramètres il faut utiliser un système d'initiation plus ou moins complexe. Dans ce papier on présente un système simple et peu coûteux pour l'initiation simultanée et parallèle de la charge explosive à deux points. Ce système se compose de l'explosif primaire - initiateur et de l'atténuateur produit en polyéthylène avec deux canaux cylindriques - point d'initiation, qui sont chargés de l'explosif plastique. Les canaux sont placés à distance de $24 \mathrm{~mm}$ l'un de l'autre mais il est possible d'utiliser n'importe quelle distance. Les essais ont confirmé que l'initiation simultanée a été réussie.

Mots clés: explosifs, charge explosive, initiation, détonation, paramètres de détonation, résultats des essais. 